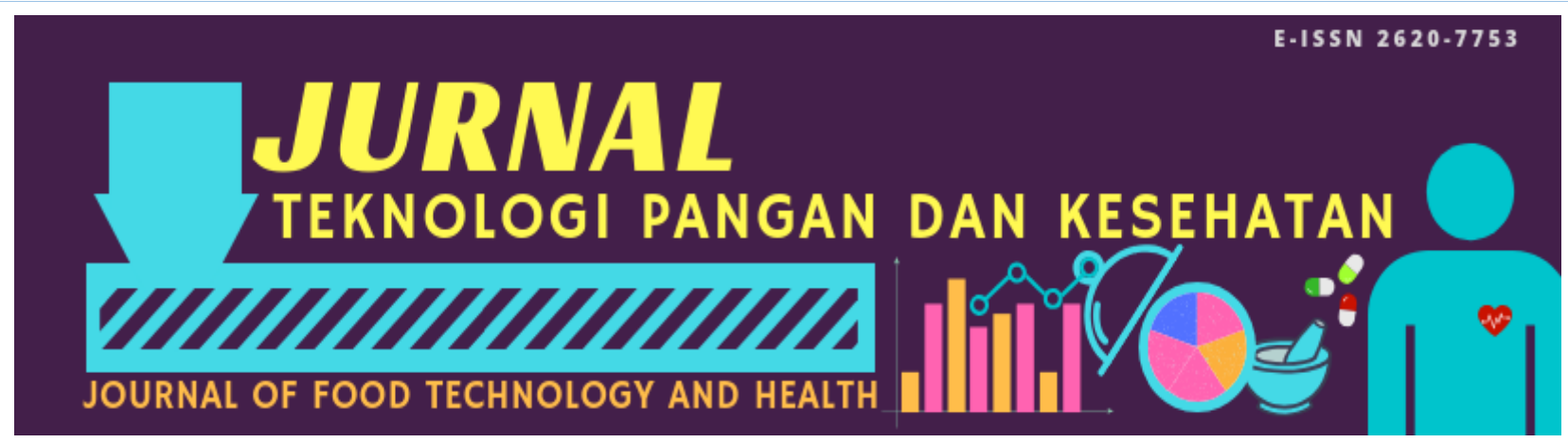

Volume I Nomor I Tahun 2019

Hasil Penelitian

Diterima 2 Feb 2019

Disetujui 27 Mei 2019

\title{
FORMULASI BAHAN MAKANAN CAMPURAN BERBAHAN DASAR KEDELAI, BERAS MERAH, DAN PISANG KEPOK UNTUK MAKANAN PENDAMPING-ASI
}

\author{
Intan Nurul Azni* \\ Universitas Sahid, Jakarta
}

\begin{abstract}
ABSTRAK: Pemberian Makanan Pendamping Air Susu Ibu (MP-ASI) merupakan hal yang penting bagi pertumbuhan bayi dengan memperhatikan baik bentuk maupun jumlahnya. Pengembangan produk MP-ASI dilakukan melalui pengembangan formula makanan tambahan yang sesuai dengan standar gizi anak berupa bahan makanan campuran (BMC). Penelitian ini bertujuan untuk mendapatkan formula bahan makanan campuran berbasis tepung kedelai, tepung beras merah, dan tepung pisang kepok yang memiliki nilai kalori dan protein yang memenuhi kebutuhan gizi pada anak berusia diatas 6 bulan. Penelitian ini terdiri dari 4 tahap, yaitu: pembuatan formula BMC, pengujian proksimat BMC, analisis organoleptik dengan uji hedonik, dan uji mikrobiologi dari formula terpilih. Bahan-bahan BMC terdiri dari tepung kedelai, tepung beras merah, tepung pisang kepok, susu skim, gula bubuk, serta minyak zaitun. Penelitian ini terdiri dari 3 formula dengan kadar tepung kedelai, tepung beras merah, dan tepung pisang kepok yang berbeda. Perbandingan tepung kedelai:tepung beras merah: tepung pisang kepok: susu skim: tepung gula: minyak zaitun pada Formula 1 (F1) adalah 30:15:15:30:5:5; F2 adalah 25:20:15:30:5:5; dan F3 adalah 25:15:20:30:5:5. Berdasarkan uji proksimat, ketiga formula telah memenuhi standar SNI MP-ASI 01-7111.1-2005 untuk kadar air. Sedangkan untuk kadar abu dan karbohidrat lebih tinggi dibanding SNI tersebut. Untuk kadar protein, F3 sudah sesuai SNI, namun F1 dan F2 di atas SNI. Untuk kadar lemak F1 dan F2 sudah sesuai dengan SNI, namun F3 di atas SNI. Berdasarkan hasil organoleptik, F3 memiliki skor yang tertinggi untuk semua parameter. Berdasarkan uji mikrobiologis, F3 sesuai standar SNI MP-ASI 01-7111.1-2005 untuk parameter MPN coliform, Escherichia coli, Salmonella sp, dan Staphylococcus aureus.
\end{abstract}

Kata Kunci: Bahan makanan campuran, beras merah, kedelai, MP-ASI, pisang kepok

ABSTRACT: Giving complementary feeding is important for infant's growth by considering both source and quantity. Developing complementary feeding products was carried out by formulating supplementary foods that are in accordance with children's nutritional standards in the form of composite foods. This study aims to obtain some formulas from the mixture of soybean flour, red rice flour, and kepok banana flour which have sufficient caloric and protein content to meet nutritional needs of children over 6 months. This study consisted of 4 steps composite foods formulation, proximate analysis, organoleptic analysis with hedonic tests, and microbiological tests for selected formulas. The ingredients of complimentary foods were soy flour, brown rice flour, kepok banana flour, skim milk, powdered sugar, and olive oil. This study consisted of 3 formulas with different levels of soy flour, brown rice flour, and kepok banana flour. The ratio of soy flour: brown rice flour: kepok banana flour: skim milk: powdered sugar: olive oil for Formula 1 (F1) was 30: 15: 15: 30: 5: 5; F2 was 25: 20: 15: 30: 5: 5; as well as F3 was 25: 15: 20: 30: 5: 5. Based on the proximate test, the three formulas met the SNI MP-ASI 01-7111.1-2005 standard for moisture content. While for ash and carbohydrate contents had a higher value than the SNI. The protein content of F3 was in accordance with SNI, but F1 and F2 were above SNI. Fat content for F1 and F2 were in accordance with SNI, but F3 was above SNI. Based on organoleptic results, F3 had the highest score for all parameters. Based on microbiological tests, F3 met with SNI MP-ASI standard 01-7111.1-2005 for MPN coliform, Escherichia coli, Salmonella sp, and Staphylococcus sp parameters.

Keywords: Complementary feeding, composite foods, kepok banana, red rice, soy bean

*Email korespondensi: inazni@gmail.com 


\section{PENDAHULUAN}

Makanan Pendamping Air Susu Ibu (MPASI) merupakan makanan atau minuman mengandung zat gizi yang diberikan pada bayi atau anak usia 6-24 bulan. MP - ASI yang jumlahnya cukup dan memenuhi kecukupan gizi diperlukan karena masa ini merupakan periode emas, untuk menjamin pertumbuhan fisik serta perkembangan kecerdasan anak (Mufida et al., 2015). Akibat kurangnya asupan zat gizi pada periode ini yaitu terjadi malnutrisi kronis/stunting. Stunting biasanya akan diiringi masalah lain seperti mudah terserang penyakit infeksi, penurunan kecerdasan dan gangguan mental (Candra, 2017).

Berdasarkan hasil RISKESDAS tahun 2018, angka baduta yang mengalami status gizi pendek adalah sebesar $17,1 \%$ sedangkan status gizi sangat pendek sebesar 12,8\% (RISKESDAS, 2018). MP-ASI pada prinsipnya harus makanan yang kaya zat gizi, mudah disajikan, mudah dicerna, mudah disimpan, higienis, dan harga terjangkau. Dalam mengembangkan produk MP-ASI, selain diversifikasi pangan yang dilandasi inovasi, juga dapat dilakukan pengembangan formula makanan tambahan yang sesuai dengan standar gizi anak berupa bahan makanan campuran (BMC) dengan perbandingan tertentu agar diperoleh suatu produk dengan nilai gizi yang tinggi seperti susu, kedelai, pisang, dan beras merah (Mufida et al., 2015).

Kedelai merupakan salah satu bahan pangan nabati yang kaya akan protein dan lemak. Di tahun 2012, produksi kedelai nasional adalah sebesar 822.066 ton (Rahayu et al., 2015). Selain mengandung protein sekitar 35\%, Kedelai juga mengandung asam amino esensial (dalam mg/100gram protein) yaitu isoleusin (5.138), leusin (8.154), lisin (4.558), valin (4.363), treonin (4.085); histidin (3.098); fenilalanin (5.385); dan triptofan (1.048) (Purawisastra et al., 1993). Oleh karena kandungan protein yang tinggi, kedelai dapat dijadikan bahan untuk BMC MP-ASI. Dalam pembuatan tepung kedelai, metode proses, suhu, dan jenis kedelai yang digunakan memengaruhi mutu dari tepung tersebut (Rani et al., 2013).
Beras merah merupakan bahan pangan sumber karbohidrat. Pertumbuhan produksi beras merah pada tahun 2005 adalah sebesar 21\% (Qohar, 2014). Karbohidrat yang dikandung oleh beras merah adalah 77,6\%. Keunggulan beras merah dibanding dengan beras putih adalah adanya kandungan antioksidan berupa antosianin sebesar 0,33$1,39 \mathrm{mg} / 100$ gram yang merupakan senyawa fenolik yang berperan baik bagi kesehatan, seperti menurunkan risiko kanker dan jantung koroner serta menangkal radikal bebas (Setiawati et al., 2013 dan Sugiarto et al., 2018). Salah satu olahan beras merah yang paling sederhana adalah tepung beras merah. Oleh karena manfaatnya, tepung beras merah dapat dijadikan bahan untuk BMC MP-ASI (Indriyani et al., 2013).

Pisang merupakan buah-buahan yang banyak dikonsumsi masyarakat. Tingkat produksi pisang pada tahun 2015 yaitu sebesar 7,3 ton dan selama 2011-2015 ratarata pertumbuhannya lebih besar $4,92 \%$ per tahun (Pusat Data dan Sistem Informasi Pertanian Kementerian Pertanian, 2016). Pisang mengandung karbohidrat sebesar 58,1\%. Selain itu pisang kaya akan mineral seperti $\mathrm{K}, \mathrm{Mg}, \mathrm{P}$, Fe, dan Ca. Tepung pisang merupakan salah satu produk olahan dari buah pisang. Tepung pisang dapat diproduksi dari semua jenis pisang. Namun pisang yang paling baik adalah pisang kepok karena memiliki kadar karbohidrat yang paling tinggi jika dibanding pisang Janten, Muli, dan Raja Nangka yaitu 88,00\%, selain itu dari segi warna pisang tersebut lebih baik dibanding ketiga pisang lainnya tersebut (Gardjito et al., 2013; Yani et al., 2013).

Penelitian ini bertujuan untuk mendapatkan formula bahan makanan campuran berbasis tepung kedelai, tepung beras merah, dan tepung pisang kepok yang memiliki nilai kalori dan protein yang cukup sehingga dapat digunakan untuk memenuhi kebutuhan gizi pada anak berusia di atas 6 bulan dengan menghitung nilai proksimat dari formula yang telah didapat, menilai tingkat kesukaannya berdasarkan skor hedonik, serta mengetahui tingkat keamanan formula secara mikrobiologis. 


\section{METODE PENELITIAN \\ Bahan dan Alat}

Bahan yang digunakan dalam pembuatan produk BMC adalah kedelai, beras merah, pisang kepok, susu skim, gula pasir, dan minyak zaitun. Kedelai, beras merah, dan pisang kepok diperoleh dari pasar KAM Jatinegara, Jakarta Timur. Alat yang digunakan berupa timbangan digital, oven microwave, talenan, pisau, piring, serbet, blender merek Panasonic MX-GX-1462, sendok, ayakan merek CBN, baskom, oven merek Binder tipe 7200, neraca analitik.

\section{Tahapan Penelitian}

Penelitian ini terdiri dari empat tahap, yaitu pembuatan formula BMC, uji proksimat, uji organoleptik dengan metode uji hedonik, uji mikrobiologis untuk formula terbaik berdasarkan uji hedonik.

\section{Pembuatan Formula}

Tepung Kedelai (Modifikasi Rani et al., 2013)

Kedelai disortasi terlebih dahulu untuk memisahkan antara bagian yang busuk, kering, atau adanya cemaran fisik seperti kerikil, benang dan lain-lain. Kemudian kedelai dicuci dan direbus selama 15 menit selanjutnya kedelai ditiriskan. Kedelai kemudian dikeringkan dalam oven merek Binder pada suhu $60^{\circ} \mathrm{C}$ selama 23 jam sampai berubah warna menjadi agak kecoklatan dan mengering. Kemudian kedelai dihaluskan dengan blender merek Panasonic dan diayak dengan menggunakan ayakan merek CBN 60 mesh.

\section{Tepung Beras Merah Tergelatinisasi} (Modifikasi Syntia, 2015)

Beras merah dicuci hingga bersih. Beras merah direndam selama 6 jam lalu ditiriskan. Beras merah yang sudah ditiriskan kemudian dikeringkan dalam oven pada suhu $50^{\circ} \mathrm{C}$ selama 29 jam. Beras merah yang sudah dioven kemudian dihaluskan dan diayak 60 mesh.

Tepung beras dan air ditimbang dengan perbandingan 1:3, kemudian dimasak hingga mengental membentuk adonan bubur pada suhu $73-75^{\circ} \mathrm{C}$. Adonan tepung beras kemudian dituang ke loyang berlapis alumunium foil untuk selanjutnya dikeringkan di oven pada suhu $60^{\circ} \mathrm{C}$.

\section{Tepung Pisang Kepok (Modifikasi Yani et al.,} 2013)

Pada pembuatan tepung pisang kepok yang harus dipilih pisang kepok dengan mutu dan spesifikasi matang, tidak cacat, dan tidak busuk, kemudian kupas pisang kepok dan dipipihkan dengan pemberat. Pisang yang sudah dipipihkan dimasukkan ke dalam oven bersuhu $60^{\circ} \mathrm{C}$ selama 16 jam. Pisang kepok didinginkan dan kemudian dihaluskan dengan menggunakan merek Panasonic MXGX-1462, selanjutnya diayak dengan ayakan merek CBN 60 mesh.

Penyusunan Komposisi Formula BMC (Modifikasi Infantriani, 2016 dan modifikasi Tamrin dan Pujilestari., 2016)

Dalam penelitian ini dibuat 3 formula yaitu Formula 1 (F1) adalah tepung kedelai:tepung beras merah:tepung pisang kepok: susu skim: tepung gula:minyak zaitun = 30:15:15:30:5:5; Formula 2 (F2) adalah tepung kedelai:tepung beras merah:tepung pisang kepok:susu skim:gula:minyak = 25:20:15:30:5:5 dan Formula 3 (F3) adalah tepung kedelai:tepung beras merah:tepung pisang kepok:susu skim:gula:minyak = 25:15:20:30:5:5.

Setelah semua bahan dicampur dan ditambah air hangat dengan perbandingan 1:2 dan dihomogenkan kemudian dioleskan pada loyang yang telah dilapisi plastik tahan panas dan dilakukan proses pengeringan kedua. Masing-masing pengeringan dilakukan pada suhu $50^{\circ} \mathrm{C}$. Bubur yang sudah kering selanjutnya dihaluskan lagi dengan blender dan diayak dengan ayakan 80 mesh.

\section{Uji Proksimat [(SNI 01-2891-1992, 1992]}

Uji proksimat terdiri dari kadar air, abu, protein, lemak, dan karbohidrat sesuai dengan SNI 01-2891-1992 tentang cara uji makanan dan minuman.

\section{Uji Organoleptik (Infantriani, 2016)}

Data yang dikumpulkan dalam penelitian adalah data primer yang didapat dari hasil uji organoleptik terhadap daya terima makanan 
formula pada aspek rasa, warna, aroma, dan tekstur. Penilaian organoleptik ini dilakukan dengan menggunakan panca indera dengan menggunakan uji hedonik. Uji hedonik diukur berdasarkan tingkat kesukaan dengan menggunakan yaitu: 5 = sangat suka, $4=$ suka, 3 = agak suka, 2 = tidak suka, 1 = sangat tidak suka. Uji organoleptik dilakukan pada 30 orang panelis. Kriteria panelis adalah dalam keadaan sehat dan tidak memiliki alergi terhadap bahan yang terdapat dalam formula, memiliki balita, dan bersedia mengikuti uji organoleptik hingga selesai (Listyoningrum dan Harijono., 2015).

Uji Mikrobiologis (BSN, 1992; BSN, 2005; FDA, 2002; FDA, 2001, ISO, 2002]

Uji mikrobiologis yang dilakukan pada penelitian ini meliputi Angka Lempeng Total (ALT) aerob, ALT anaerob, coliform, Escherichia coli, Salmonella sp, dan Staphylococcus aureus. Analisis ALT aerob dan anaerob menggunakan teknik cawan tuang dengan media PCA yang diinkubasi pada kondisi aerob maupun anaerob [(SNI) 01-2891-1992 dan (SNI) 01-7111.1-2005]. Uji coliform dan Escherichia coli menggunakan metode BAM 2002 chapter 4, Staphylococcus aureus menggunakan metode BAM 2001 chapter 12, dan Salmonella sp menggunakan metode ISO 6579:2002 (E).

\section{HASIL DAN PEMBAHASAN \\ Proksimat}

Nilai proksimat terdiri atas kadar air, abu, protein, lemak, dan karbohidrat. Nilai proksimat BMC MP-ASI tepung kedelai, tepung beras merah, dan tepung pisang kepok dapat dilihat pada Tabel 1. Berdasarkan SNI 01-7111.1-2005 mengenai MP-ASI bubuk instan, ketiga formula telah memenuhi standar SNI tersebut untuk kadar air. Berdasarkan SNI, kadar air untuk produk MP-ASI bubuk instan adalah tidak lebih dari 4 gram per 100 gram produk.

Kadar abu ketiga formula memiliki nilai lebih tinggi dibanding SNI. Berdasarkan SNI, kadar abu untuk produk MP-ASI bubuk instan adalah tidak lebih dari 3,5 gram per 100 gram produk. Kadar karbohidrat untuk ketiga formula juga memiliki nilai yang lebih tinggi dibanding SNI. Berdasarkan SNI, jumlah karbohidrat yang ditambahkan tidak lebih dari 7,5 gram per $100 \mathrm{kkal}$ atau 30 gram per 100 gram produk.

Tabel 1. Nilai proksimat BMC MP-ASI tepung kedelai, tepung beras merah, dan tepung pisang kepok (per $100 \mathrm{~g}$ )

\begin{tabular}{lcccc}
\hline Parameter (\%) & F1 & F2 & F3 & SNI* \\
\hline Air & 2,89 & 3,06 & 3,57 & $<4$ \\
Abu & 4,26 & 4,16 & 4,08 & $<3,5$ \\
Protein & 22,2 & 23,6 & 21,7 & $8-22$ \\
Lemak & 11,8 & 13,3 & 19,8 & $6-15$ \\
Karbohidrat & 58,8 & 55,9 & 50,8 & $<30$ \\
\hline *SNI 01-7111.1-2005 & & & &
\end{tabular}

Kadar protein formula 3 (F3) sudah sesuai SNI, namun formula 1 (F1) dan formula 2 (F2) di atas SNI. Berdasarkan SNI, kandungan protein pada MP-ASI bubuk instan tidak kurang dari 2 gram per 100 kkal atau 8 gram per 100 gram produk dan tidak lebih dari 22 gram per 100 gram produk. Protein merupakan zat gizi yang sangat dibutuhkan bagi tumbuh kembang bayi, sehingga dibutuhkan protein yang cukup untuk menunjang pertumbuhan dan perkembangannya (Purnamasari dan Harijono, 2014).

Kadar lemak F1 dan F2 sudah sesuai, namun F3 di atas SNI. Berdasarkan SNI, kandungan lemak pada MP-ASI bubuk instan tidak kurang dari 1,5 gram per 100 kkal atau 6 gram per 100 gram dan tidak lebih dari 3,75 gram per $100 \mathrm{kkal}$ atau 15 gram per 100 gram produk. Namun nilai ini masih sesuai dengan penelitian Soetrisno dan Julianti (2007) dimana kandungan lemak pada MP-ASI sebesar 25\% dari 100 gram produk. Penelitian tersebut terdiri dari 4 formula, F1terdiri dari tepung beras, ikan pari, wortel, sagu, kedelai, minyak, dan jus rumput laut; F2 terdiri dari jagung manis, cucut, katuk, sagu, kedelai, minyak, dan jus rumput laut; F3 terdiri dari ubi merah, tongkol, bayam, sagu, kedelai, minya, dan jus rumput laut; F4 terdiri dari pisang oli, kwee, caisim, sagu, kedelai, minyak, dan jus rumput laut.

\section{Organoleptik}

Hasil analisis organoleptik pada penelitian terdapat pada Tabel 2 . 
Tabel 2. Nilai skor hedonik BMC MP-ASI tepung kedelai, tepung beras merah, dan tepung pisang kepok

\begin{tabular}{cccc}
\hline Parameter & F1 & F2 & F3 \\
\hline Rasa & $2,9 \pm 1,1$ & $3,1 \pm 1,1$ & $3,2 \pm 1,1$ \\
Warna & $3,0 \pm 0,9$ & $3,0 \pm 0,9$ & $3,1 \pm 0,9$ \\
Aroma & $3,1 \pm 1,0$ & $3,2 \pm 1,2$ & $3,3 \pm 1,0$ \\
Tekstur & $2,5 \pm 0,9$ & $2,8 \pm 1,0$ & $3,2 \pm 1,1$ \\
\hline
\end{tabular}

Berdasarkan hasil uji hedonik/tingkat kesukaan, didapatkan F3 memiliki skor paling tinggi untuk semua parameter (rasa, warna, aroma, dan tekstur). Di antara ketiga formula BMC MP-ASI ini, F3 memiliki jumlah penambahan tepung pisang yang lebih banyak. Hal ini menunjukkan bahwa panelis lebih menyukai sensori dari tepung pisang dibandingkan dengan tepung kedelai dan tepung beras merah.

Menurut penelitian Purwanto dan Hersoelistyorini (2011), MP-ASI yang mengandung tepung kedelai tinggi memiliki tingkat sensori yang rendah, hal ini disebabkan rasanya yang agak pahit. Rasa pahit ini disebabkan adanya senyawasenyawa glikosida dalam biji kedelai yaitu soyasaponin dan sapogenol. Selain itu enzim lipoksigenase yang terdapat pada kedelai akan menghidrolisis atau menguraikan lemak kedelai sehingga menghasilkan bau langu. Tepung pisang mampu menutupi aroma langu yang dihasilkan oleh tepung kedelai (Ardhianditto et al., 2013).

\section{Mikrobiologis}

Uji mikrobiologis hanya dilakukan pada formula terpilih berdasarkan uji organoleptik yaitu F3. Berdasarkan hasil uji mikrobiologis, didapatkan bahwa F3 masih sesuai dengan SNI MP-ASI bubuk instan (01-7111.1-2005) pada parameter ALT aerob, Coliform, Escherichia coli, Salmonella sp, Staphylococcus aureus. Hasil ALT anaerob menunjukkan nilai yang lebih tinggi dibanding SNI. Namun setelah dikonfirmasi melalui uji Coliform, Escherichia coli, Salmonella sp, Staphylococcus aureus hasil yang didapatkan adalah masih dalam batas SNI. Hal ini menunjukkan formula tersebut aman secara mikrobiologis untuk dikonsumsi oleh bayi.
Tabel 3. Hasil uji mikrobiologis formula terpilih BMC MP-ASI tepung kedelai, tepung beras merah, dan tepung pisang kepok

\begin{tabular}{|c|c|c|}
\hline Uji & Hasil & SNI* \\
\hline ALT aerob & $\begin{array}{c}0,5 \times 10^{4} \\
\text { koloni/gram }\end{array}$ & \multirow{2}{*}{$\begin{array}{l}<1 \times 10^{4} \\
\text { koloni/gram }\end{array}$} \\
\hline ALT anaerob & $\begin{array}{c}1,8 \times 10^{2} \\
\text { koloni/gram }\end{array}$ & \\
\hline Coliform & <3 APM/gram & $\begin{array}{c}<20 \\
\text { APM/gram }\end{array}$ \\
\hline E. coli & $<3$ APM/gram & Negatif \\
\hline Salmonella sp & $\begin{array}{l}\text { Negatif/25 } \\
\text { gram }\end{array}$ & $\begin{array}{l}\text { Negatif/25 } \\
\text { gram }\end{array}$ \\
\hline $\begin{array}{l}\text { Staphylococcus } \\
\text { aureus }\end{array}$ & 0 koloni/gram & $\begin{array}{c}<1,0 \times 10^{2} \\
\text { koloni/gram }\end{array}$ \\
\hline
\end{tabular}

Uji Angka Lempeng Total merupakan suatu metode kuantitatif yang digunakan untuk mengetahui jumlah keseluruhan mikroba yang terdapat pada suatu sampel. Nilai ALT pada bahan pangan mengindikasikan banyaknya jumlah mikroba yang meliputi bakteri, kapang, dan khamir. Nilai ALT menunjukkan kualitas suatu bahan pangan, sehingga semakin tinggi nilai TPC, semakin rendah pula kualitas suatu bahan makanan. Jenis mikroba yang umumnya pada makanan berupa serbuk adalah kapang. Penelitian Danarsi dan Noer (2016), berupa MP-ASI berbahan dasar tepung labu kuning dan tepung ikan gabus menunjukkan nilai ALT yang masih di bawah ambang batas SNI 01-7111.1-2005 sehingga dikategorikan aman.

Berdasarkan hasil uji, ditemukan angka Salmonella sp yang negatif. Hal ini disebabkan proses pengolahan MP-ASI ini yang melalui proses $2 \mathrm{x}$ pengeringan menggunakan oven dengan suhu $50^{\circ} \mathrm{C}$. Temperatur optimum untuk pertumbuhan Salmonella sp adalah 37$45^{\circ} \mathrm{C}$ (Danarsi dan Noer., 2016).

\section{KESIMPULAN}

BMC pada penelitian ini merupakan campuran dari tepung kedelai, tepung beras merah, tepung pisang kepok, susu skim, tepung gula, dan minyak zaitun. Formula pada penelitian ini terdiri dari 3 formula yaitu F1 30:15:15:30:5:5; F2 25:20:15:30:5:5; F3 25:15:20:30:5:5. Berdasarkan uji proksimat, formula terbaik adalah F3, karena sesuai dengan ketentuan MP-ASI pada SNI MP-ASI 01-7111.1-2005 untuk kadar air dan 
kadar protein. Berdasarkan hasil organoleptik, F3 memiliki skor yang tertinggi untuk semua parameter sensori (rasa, warna, aroma, dan tekstur). Berdasarkan uji mikrobiologis, F3 sesuai dengan standar SNI MP-ASI 01-7111.1-2005 dalam parameter MPN coliform, Escherichia coli, Salmonella sp, dan Staphylococcus aureus.

\section{UCAPAN TERIMA KASIH}

Terima kasih kepada Universitas Sahid Jakarta yang telah membiayai penelitian ini melalui Penelitian Hibah Internal tahun 2017.

\section{DAFTAR PUSTAKA}

Ardhianditto, D., Anandito, R.B.K., Parnanto, N.H.R., \& Rahmawati, D., 2013. Kajian karakteristik bubur bayi instan berbahan dasar tepung millet kuning (Panicum $s p$ ) dan tepung beras merah (Oryza nivara) dengan flavor alami pisang ambon (Musa $x$ paradisiaca I) sebagai makanan pendamping ASI (MP-ASI). Jurnal Teknosains Pangan, 2(1), hal. 88-96.

Candra, A., 2017. Suplementasi mikronutrien dan penanggulangan malnutrisi pada anak usia di bawah lima tahun (Balita). JNH, 5(3), hal. 1-8.

Danarsi, C.S., \& Noer, E.R., 2016. Pengaruh lama penyimpanan terhadap mutu mikrobiologi makanan pendamping air susu ibu (MP-ASI) bubur instan dengan substitusi tepung ikan gabus dan tepung labu kuning. Journal of Nutrition College, 5(2), hal. 58-63.

Gardjito, M., Djuwardi, A., \& Harmayani, E., 2013. Pangan nusantara: karakteristik dan prospek untuk percepatan diversifikasi Pangan. Kencana Prenada Media Group, Jakarta.

Indriyani, F., Nurhidajah, \& Suyanto, A., 2013. Karakteristik fisik, kimia dan sifat organoleptik tepung beras merah berdasarkan variasi lama pengeringan. Jurnal Pangan dan Gizi, 4(8), hal. 27-43.

Infantriani, A.S., 2016. Pengembangan bahan makanan campuran berbasis tepung kacang hijau dengan nilai mutu protein yang tinggi untuk balita gizi kurang. Fakultas Kesehatan Universitas MH Thamrin Jakarta.
International Organization for

Standardization (ISO), 2002. ISO 6579:2002: Microbiology of food and animal feeding stuffs -- Horizontal method for the detection of Salmonella spp [Online] Tersedia di https://www.iso.org/standard/29315.ht ml. [Diakses pada tanggal 25 Maret 2019].

Kementerian Kesehatan Republik Indonesia, 2018. Hasil Utama RISKESDAS 2018 [Online] Tersedia di http://www.depkes.go.id/resources/dow nload/infoterkini/materi_rakorpop_2018/Hasil\%20 Riskesdas\%202018.pdf. [Diakses pada tanggal 25 Maret 2019].

Listyoningrum, H., \& Harijono, 2015. Optimasi susu bubuk dalam makanan pendamping ASI (MP-ASI). Jurnal Pangan dan Agroindustri, 3(4), hal. 1302-1312.

Mufida, L., Widyaningsih, T.D., \& Maligani, J.M., 2015. Prinsip dasar makanan pendamping air susu ibu mp-asi untuk bayi 6-24 bulan: kajian pustaka. Jurnal Pangan dan Agroindustri, 3(4), hal. 164651.

Purawisastra, S., Slamet, D.S., \& Soetrisno, U.S.S., 1993. Perubahan kandungan protein dan komposisi asam amino kedelai pada waktu pembuatan tempe dan tahu. Penelitian Gizi dan Makanan, 16, hal. 117124.

Purnamasari, E.W., \& Harijono, 2014. Optimasi kadar kalori dalam makanan pendamping ASI (MP-ASI). Jurnal Pangan dan Agroindustri, 2(3), hal. 19-27.

Purwanto, \& Hersoelistyorini W., 2011. Studi pembuatan makanan pendamping asi (MP-ASI) menggunakan campuran tepung kecambah kacang kedelai, kacang hijau, dan beras. Jurnal Pangan dan Gizi, 2(3), hal. 43-54.

Pusat Data dan Sistem Informasi Pertanian Kementerian Pertanian. 2016. Outlook Komoditas Pertanian Sub Sektor Hortikultura [Online] Tersedia di http://perpustakaan.bappenas.go.id/lont ar/file?file=digital/167090-[_Konten_]Konten\%20D1900.pdf. [Diakses pada 25 Maret 2019]. 
Qohar, R.A., 2014. Analisis kelayakan pengembangan usaha beras merah organik (studi kasus: UD Sirtanio, Banyuwangi, Jawa Timur). Fakultas Ekonomi dan Manajemen Institut Pertanian Bogor.

Rahayu, S., Srihadi, E., Mahardika, H., Subroto, A., Chalid, D.A., Cholid, S., \& Rumantir, V.W., 2015. Studi identifikasi ketahanan pangan \& preferensi konsumen terhadap konsumsi bahan pangan pokok kedelai. Kementerian PPN/BAPPENAS, Jakarta.

Rani, H., Zulfahmi, \& Widodo, Y.R., 2013. Optimasi proses pembuatan bubuk (tepung) kedelai. Jurnal Penelitian Pertanian Terapan, 13(3), hal. 188-96.

Setiawati, H., Marsono Y., \& Sutedja A.M., 2013. Kadar antosianin dan aktivitas antioksidan flake beras merah dan beras ketan hitam dengan variasi suhu perebusan. Jurnal Teknologi Pangan dan Gizi, 12(1), hal. 29-38.

Soetrisno, U., \& Julianti, E.D., 2007. Pengembangan makanan formula anak balita menggunakan berbagai jenis ikan laut dan rumput laut. PGM, 30(1), hal. 1-7.

Standar Nasional Indonesia (SNI) 01-28911992, 1992. Cara uji makanan dan minuman. Badan Standardisasi Nasional, Jakarta.

Standar Nasional Indonesia (SNI) 01-7111.12005, 2005. Makanan pendamping air susu ibu (MP-ASI)-bagian 1: bubuk instan. Badan Standardisasi Nasional, Jakarta.
Sugiarto, R., Kristanto, B.A., \& Lukiwati, D.R., 2018. Respon pertumbuhan dan produksi padi beras merah (Oryza nivara) terhadap cekaman kekeringan pada fase pertumbuhan berbeda dan pemupukan nanosilika. J. Agro. Complex, 2(2), hal. 169179.

Syntia, I.A., 2015. Formulasi tepung tempe dan tepung ikan teri nasi terhadap mutu bubur bayi instan. Fakultas Teknologi Pangan dan Kesehatan Universitas Sahid Jakarta.

Tamrin R., \& Pujilestari S., 2016. Karakteristik bubur bayi instan berbahan dasar tepung garut dan tepung kacang merah. Konversi, 5(2), hal. 49-58.

US Food \& Drug Administration (FDA), 2001. BAM: Staphylococcus aureus [Online] (diupdate 31 Oktober 2017) Tersedia di https://www.fda.gov/food/foodsciencere search/laboratorymethods/ucm071429.h tm. [Diakses pada tanggal 25 Maret 2019].

US Food \& Drug Administration (FDA), 2002. $B A M$ 4: Enumeration of Escherichia coli and the Coliform Bacteria [Online] (diupdate 5 Juli 2018) Tersedia di https://www.fda.gov/food/foodsciencere search/laboratorymethods/ucm064948.h tm. [Diakses pada tanggal 24 Maret 2019]. Yani, A., Arief, R.W., \& Mulyanti, N., 2013. Processing of banana flour using a local banana as raw materials in Lampung. International Journal on Advanced Science Engineering Information Technology, 3(4), pp. 26-30.

\section{BIODATA}

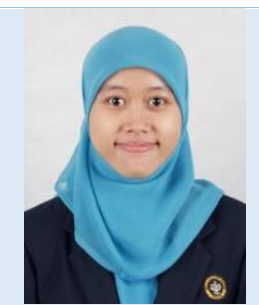

Intan Nurul Azni, S.Km., M.Si., dilahirkan pada 4 Januari 1988. Pada tahun 2009 menyelesaikan studi pada program studi Gizi Kesehatan Masyarakat Universitas Indonesia. Pada tahun 2013 menyelesaikan studi pada program magister Ilmu Pangan IPB. Saat ini sebagai staf pengajar Universitas Sahid Jakarta pada program studi Teknologi Pangan

Jurnal Teknologi Pangan dan Kesehatan (The Journal of Food Technology and Health)

Memuat artikel ilmiah berupa hasil penelitian bidang teknologi pangan dan gizi

Diterbitkan oleh Fakultas Teknologi Pangan dan Kesehatan, Universitas Sahid, Jakarta

Web: http://jurnal.usahid.ac.id/index.php/teknologi_pangan; E-mail: jtepakes@gmail.com 